\title{
Generalised edema with human parvovirus B19 infection
}

\author{
Satoshi Hayano (10 , ${ }^{1}$ Hideto Oshikawa ${ }^{2}$
}

${ }^{1}$ Department of Internal Medicine, Japanese Red Cross Kumamoto Hospital, Kumamoto, Japan

${ }^{2}$ Department of Rheumatology, Japanese Red Cross Kumamoto Hospital, Kumamoto, Japan

\section{Correspondence to}

Dr Satoshi Hayano;

059m2076@gmail.com

Accepted 29 May 2021

Check for updates

(C) BMJ Publishing Group Limited 2021. No commercial re-use. See rights and permissions. Published by BMJ.

\begin{tabular}{|l|}
\hline To cite: Hayano S, \\
Oshikawa H. BMJ Case \\
Rep 2021;14:e243130. \\
doi:10.1136/bcr-2021- \\
243130 \\
\hline
\end{tabular}

\section{DESCRIPTION}

A 46-year-old woman presented with a 14-day history of generalised oedema and shortness of breath and a weight gain of $6 \mathrm{~kg}$ in 1 week. One month previously, she experienced high-grade fever and malaise without arthralgia. The fever spontaneously resolved after 1 week, but slight erythema was observed on her trunk and limbs. She had not taken any medications. We observed bilateral pitting oedema of the lower legs (pit recovery time $>20$ s; figure 1 ) and forearms. Her heart and lung sounds were normal.

The results of the initial laboratory tests were as follows: leucocyte count, $4.63 \times 10^{9} / \mathrm{L}$; haemoglobin, $100 \mathrm{~g} / \mathrm{L}$; red blood cell count, $3.14 \times 10^{12} / \mathrm{L}$; mean corpuscular volume, $98.1 \mathrm{fL}$; platelet count, $222 \times 10^{9} / \mathrm{L}$; serum creatinine, $1.02 \mathrm{mg} / \mathrm{dL}$; blood urea nitrogen, $18.4 \mathrm{mg} / \mathrm{dL}$; total-bilirubin, $0.5 \mathrm{mg} / \mathrm{dL}$; aspartate aminotransferase, $38 \mathrm{U} / \mathrm{L}$; alanine aminotransferase, 47U/L; serum lactate dehydrogenase, $280 \mathrm{U} / \mathrm{L}$; free T4, $1.05 \mathrm{ng} / \mathrm{dL}$; thyroid-stimulating hormone, $0.90 \mu \mathrm{IU} / \mathrm{mL}$; serum albumin, $3.0 \mathrm{~g}$ $\mathrm{dL}$ and $\mathrm{C}$ reactive protein, $0.24 \mathrm{mg} / \mathrm{dL}$. Urinalysis showed no hematuria or proteinuria. Brain natriuretic peptide level $(194.2 \mathrm{pg} / \mathrm{mL})$ was elevated; and rheumatoid factor and antinuclear antibody levels were normal. Chest X-ray showed bilateral pleural effusion (figure 2). Additional laboratory tests were positive for anti-human parvovirus B19 (anti-B19V) IgM (9.80) using enzyme immunoassays. A diagnosis of B19V infection with generalised pitting oedema was made. Symptoms improved following diuretic administration for 1 week (figures 1 and 2).

B19V infection in immunocompetent adults often presents with arthralgia, and typical facial rash with slapped-cheek appearance is rare. ${ }^{1}$ There were few reports of generalised oedema in adults. ${ }^{1-4}$ This case did not occur during an epidemic of B19V, however, it has been reported that generalised oedema were often observed during the $\mathrm{B} 19 \mathrm{~V}$ epidemic. ${ }^{4}$ Compared with $\mathrm{B} 19 \mathrm{~V}$-induced fetal hydrops, cardiac failure and hemolysis are unlikely to be the cause of oedema in adults. In this case, causes of oedema such as abnormal thyroid function, hypoalbuminaemia, liver cirrhosis and glomerulonephritis could be excluded from the physical examination and laboratory findings. The

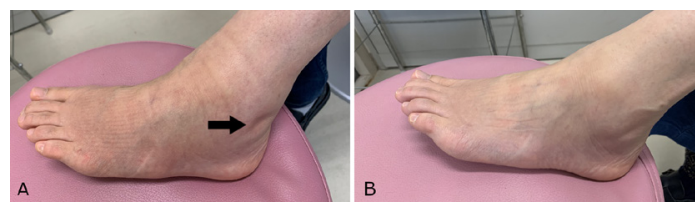

Figure 1 Pitting oedema ( $A$, arrow) resolved after 2 weeks (B).

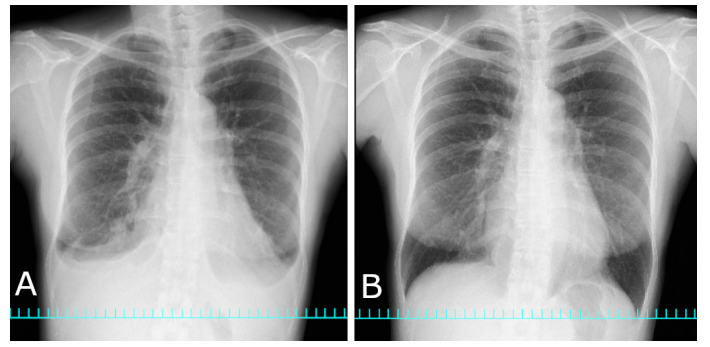

Figure 2 Pleural effusion (A) resolved after 2 weeks (B).

mild normocytic anaemia improved spontaneously and was determined to be due to a transient viral infection. Physical examination and normal ECG and echocardiography results showed no signs of myocarditis, pericarditis or heart failure. It was suggested that mildly elevated BNP was due to the atrial volume over load caused by the transient increase in fluid volume.

Generalised oedema without heart or renal failure caused by parvoviruses has been reported. The presentation of generalised oedema suggests a capillary leak syndrome-like mechanism, but the aetiology remains to be elucidated. ${ }^{1}$ The time from onset to appearance of oedema is often delayed (4-13 days), with a weight gain of $2.5-7 \mathrm{~kg}$.

In general, the prevalence of $\mathrm{B} 19 \mathrm{~V}$-specific antibodies increases with age, however, it has been reported that about half of women of childbearing age was negative for human parvovirus $\mathrm{IgG} .^{5}$ $\mathrm{B} 19 \mathrm{~V}$ infection should be considered as a differential diagnosis of acute pitting oedema especially in susceptible adults with a recent history of infection.

\section{Learning points}

Human parvovirus B19 (B19V) infection is a rare cause of an acute generalised oedema in adults.

- Unlike B19V-induced fetal hydrops, the generalised oedema in adults is rarely caused by heart failure, but the mechanism is still unknown.

- The oedema with B19V infection is selfremitting but some cases need diuretics for excessive retention of body fluids.

Contributors $\mathrm{SH}$ : conceptualisation, writing, original draft preparation and HO: writing, reviewing and editing, supervising.

Funding The authors have not declared a specific grant for this research from any funding agency in the public, commercial or not-for-profit sectors.

Competing interests None declared.

Patient consent for publication Obtained. 
Images in...

Provenance and peer review Not commissioned; externally peer reviewed.

\section{ORCID ID}

Satoshi Hayano http://orcid.org/0000-0003-3554-1600

\section{REFERENCES}

1 Broliden K, Tolfvenstam T, Norbeck 0. Clinical aspects of parvovirus B19 infection. J Intern Med 2006;260:285-304.

2 Wiggli B, Imhof E, Meier CA, et al. Water, water, everywhere. The Lancet 2013;381:776.
3 Vlaar PJ, Mithoe G, Janssen WM. Generalized edema associated with parvovirus B19 infection. Int J Infect Dis 2014;29:40-1.

4 Nakazawa T, Machi T, Kitagawa S, et al. Parvovirus infection and generalized edema in adults. Intern Med 1995;34:163-5.

5 Ihara T, Furusyo N, Hayashi T, et al. A population-based epidemiological survey of human parvovirus B19 infection: a project of the Kyushu and Okinawa population study (KOPS). Arch Virol 2013;158:2465-72.

6 Rogo LD, Mokhtari-Azad T, Kabir MH, et al. Human parvovirus B19: a review. Acta Virol 2014;58:199-213.

Copyright 2021 BMJ Publishing Group. All rights reserved. For permission to reuse any of this content visit

https://www.bmj.com/company/products-services/rights-and-licensing/permissions/

BMJ Case Report Fellows may re-use this article for personal use and teaching without any further permission.

Become a Fellow of BMJ Case Reports today and you can:

- Submit as many cases as you like

- Enjoy fast sympathetic peer review and rapid publication of accepted articles

- Access all the published articles

Re-use any of the published material for personal use and teaching without further permission

\section{Customer Service}

If you have any further queries about your subscription, please contact our customer services team on +44 (0) 2071111105 or via email at support@bmj.com.

Visit casereports.bmj.com for more articles like this and to become a Fellow 